Open Access

\title{
An application of growth diagnostics on the growth of firms: with evidence from Kosovo firms
}

\author{
Fadil Sahiti ${ }^{*}$ (D) and Helen Lawton Smith ${ }^{2}$
}

\author{
* Correspondence: \\ fadilsahiti@yahoo.com \\ ${ }^{1}$ Rochester Institute of Technology \\ (R.I.T), Prishtina, Kosovo \\ Full list of author information is \\ available at the end of the article
}

\begin{abstract}
This paper provides evidence on the impact of the business environment on the growth of firms in less-developed countries, with evidence from Kosovo firms. The theoretical perspective used is growth diagnostics. The data used to test the hypotheses were obtained from two different sources: international surveys and a manager survey dataset. The findings show that the business environment in Kosovo provides little incentive for firm growth. Further, empirical evidence shows that the business environment in Kosovo is characterised by low appropriability, with a high cost of capital, and in which complementary factors in the form of human capital are scarce.
\end{abstract}

Keywords: Public goods, Constraints on growth, Infrastructure, Finance, Institutions, Firmlevel data

\section{Background}

Intending to create economic value, firms react to their business environment in different ways. In most cases this reaction is affected by factors outside the firm's control. In literature these factors are known as business environment factors. The ones most commonly explored by empirical studies include physical infrastructure, the legal system, the financial system, various aspects of the micro and macro policy environment such as taxation, regulation, macroeconomic stability and social factors such as crime and corruption in a society (Carlin and Seabright 2007).

By using information from various international and national sources, the purpose of this paper is not only to examine the set of constraints to the growth of firms but also to find out which of these constraints is the most binding. The methodology also follows two steps. The first is to find out which constraints are indicated to be significant among the set of constraints. The second is to identify the most binding constraint. Findings indicate that the most binding constraint is related to appropriability factors. Several symptoms point out that government in the country fails to provide necessary public goods. This is indicated by micro-risk factors such as unfair competitive practices, rule of law, and high levels of corruption. Appropriation factors are followed by access to finance and complementary factors in the form of human capital as constraints that matter the most for growth.

(c) The Author(s). 2017 Open Access This article is distributed under the terms of the Creative Commons Attribution 4.0 International License (http://creativecommons.org/licenses/by/4.0/), which permits unrestricted use, distribution, and reproduction in any medium, provided you give appropriate credit to the original author(s) and the source, provide a link to the Creative Commons license, and indicate if changes were made. 
Data analysis was carried out by applying the growth diagnostics (hereafter the GD approach) approach and methodology proffered by Hausmann et al. (2008). This approach provides a theoretical framework to identify the most binding constraints on economic growth in general. The approach recognises that constraints on the growth of a developing economy are numerous and that previous approaches to reforms and growth are either unrealistic or wrong (Hausmann et al. 2005). The approaches are unrealistic because wholesale reforms that attempt to eliminate all obstacles at the same time are not possible, and wrong because by hoping to do as many reforms as possible in the current prevailing approach go against the principle of second best. It is evident that GD approach is centred on a macro level. However, according to Hausmann et al. (2008): 22, the key problem of growth is related to low levels of private investment and entrepreneurship. In that respect, GD is a de facto micro-based perspective on growth, i.e. it assumes that constraints to growth are essentially micro. Accordingly, GD is concerned with the issue of what is preventing private firms, or private agents, expanding their business activities or why there is a low level of entrepreneurship.

There are three classes of variables on which the theoretical perspective of this paper is based. The first class of variables is related to complementary factors such as geography, low human capital, and poor infrastructure. The second class involves variables related to profit appropriation represented by government properties including corruption, taxes, crime, judicial system, political stability, uncertain economic policies, regulations, and market properties such as information failure and coordination failure. ${ }^{1}$ The third class of variables covers variables such as those related to access to external finance.

Growth diagnostics methodology has been well established through the work of Hausman and Rodrick, among others, and has been widely applied, including in Kosovo. ${ }^{2}$ This is, effectively, an alternative to the econometric approach most commonly used in this kind of study. As such it offers an approach which may be understandable to a wider range of audience and readership. The paper also employs an original dataset which is not easily available for similar economies and creates the opportunity to apply the GD approach to the growth of firms in Kosovo. The results of the study confirm the findings of similar studies in other countries, something which supports the use of this approach. However, there are very few studies which have specifically applied this approach to address growth issues at a micro level. Hence, this paper contributes to the existing literature by applying it specifically in investigating factors that constrain firm growth. Another contribution to the literature is related to the fact that while all of previous studies have followed only the top-down approach in the investigation of binding constraints to the economic growth, this study uses both a top-down approach and a bottom-up approach (from firm-level data) to investigate business environment constraints to the growth of firms.

The paper is organised as follows. The next section reviews the literature. Section 3 presents an overview of the methodology and describes the data used. The fourth section presents a macroeconomic overview of the country. The fifth section presents symptoms derived from the investigation. The sixth section provides the lists of syndromes identified. Section 7 discusses some limitations of the study and the approach applied, while the last one provides concluding remarks. 


\section{Business environment literature review}

Extensive empirical evidence suggests that a favourable business environment promotes the growth of firms, while many of them indicate that firms in developing countries face a tougher business environment (Rodrik et al. 2004; Dollar et al., 2005; Carlin et al. 2006; Dinh et al., 2010; Lee 2014). Since the analysis of data for this study is carried out focusing on three sets of variables, this review does the same, namely discusses findings of other studies related to human capital and infrastructure, quality of institutions, and the effects of access to finance on the growth of firms.

Many other studies view human capital as a critical underlying mechanism that enables the firm to recognise its heterogeneous resources and capabilities (Barney et al. 2011). For over 20 years researchers involved in the development of human resource capital have tried to explain why some firms outperform others (Barney 1991, 2001; Acedo et al. 2006). A common finding in the literature is that human capital plays a crucial role in the growth of firms (Kogut and Zander, 1992; Grant, 1991, Grant 1996; Tell 2015). Further, this evidence suggests that transition countries stand relatively well in terms of formal measures of education, and CEE economies continue to invest a high proportion of GDP on education, even outperforming some West European countries (Davidsson and Honig 2003; Barr et al. 2005). Estrin et al. (2006) found evidence indicating that transition economies typically have a high proportion of students in 'hard' subjects of science, mathematics, and engineering. Similarly, there is a significant body of research aiming to explain the impact of physical infrastructure on the growth of firms. The evidence shows that, for instance, access to electricity has heterogeneous effects: small- and medium-size firms are often affected by power cuts, while large and micro firms tend not to be (Dinh et al., 2010; Aterido et al. 2009, Aterido and Hallward-Dreimeier 2011). The main reason is that micro firms use less energyintensive tools and large firms are more likely to secure their own energy supply (Gelb et al. 2007). Thus infrastructure such as the power supply has more direct effect on the growth rate of small- and medium-size firms, but has only an indirect effect on the growth rate of larger firms (Dinh et al., 2010, Aterido and Hallward-Dreimeier 2010).

Several institutional aspects are argued to affect firm growth such as the strength of legal enforcement, administrative barriers to entry, the prevalence of extra-legal payments and a lack of market-supporting institutions (Johnson et al. 2000; Estrin et al. 2006, 2009). According to Svejnar (2002), the legal and institutional system which underlies a market economy is immature in most transition economies, having only been introduced in many countries since 1990. As countries in Central and Eastern Europe have inherited a stronger legal, institutional, and cultural framework, this initial advantage enabled these countries to develop a better market economy, which in turn had a positive impact on the firm growth (Bevan and Estrin 2004; Mickiewicz 2005). Taxes are a common complaint from firms worldwide (Rosen 2005). In transition economies the issue of taxes is often related to the costs created by an inefficient, inconsistent, and/or corrupt system of tax collection, which in turn may substantially add to the costs of running firm activities (Aidis and Mickiewicz 2006). Corruption is one of the most interesting institutional characteristics which is likely to have a significant impact on firm growth and on entrepreneurship in general (McMillan and Woodruff 2002). According to Aidis and Mickiewicz (2006), corruption has damaging effects on entrepreneurial activity and firm expansion because it increases the level of uncertainty and 
reduces entrepreneurial gains. Corruption is often seen as one of the key outcome variables reflecting all institutional weaknesses in an economic setting (Aidt 2011). Aidis and Mickiewicz (2006) argue that corruption has been an important obstacle to business expansion in transition economies.

Among other factors, access to external finance is one of the most important aspects discussed in the literature. The evidence shows that better access to external finance is likely to be one of the most effective routes to promoting firm growth (Pissarides 1999; Filatotchev and Mickiewicz 2006; Hashi and Toci 2010; Wehinger 2014).

In summary, aiming to identify factors that constrain the growth of firms, researchers have identified a varying range of factors. They have used various approaches and methodologies, and sometimes they have generated contradictory results (Carlin and Seabright 2007). According to Rodrik (2010) researchers should stop acting as categorical advocates for specific approaches to growth. They should instead be diagnosticians, that is, adapt approaches and methodologies that do not substitute but rather complement each other, also use models which enable navigation through varying contexts and realities. He claims that a growth diagnostics approach offers a more systematic approach to contextualising the research, which in turn leads to the identification of binding constraints to the growth of a specific activity. This approach is based on the combination of a simple theory and suggestive empirics (Rodrik 2010).

\section{Methodology and data}

The methodology used in this paper builds on the growth diagnostics framework developed by Hausmann et al. (2008), which argues that there might be many reasons why firms do not grow, but each reason generates a specific set of symptoms. ${ }^{3}$ These symptoms then constitute the basis for differential diagnosis through which, based on several sources of empirical evidence, syndromes are distinguished. ${ }^{4}$ Therefore, the methodology applied in this study provides strategies and steps to find out what these symptoms and syndromes are. The process of analysis is carried out through the following decision tree: (Fig. 1).

The decision tree represents the root cause analysis diagram and as such is read from top to bottom, and not side to side, or bottom to top (Hausmann et al. 2008). As previously mentioned, the central assumption of the growth diagnostics perspective is that

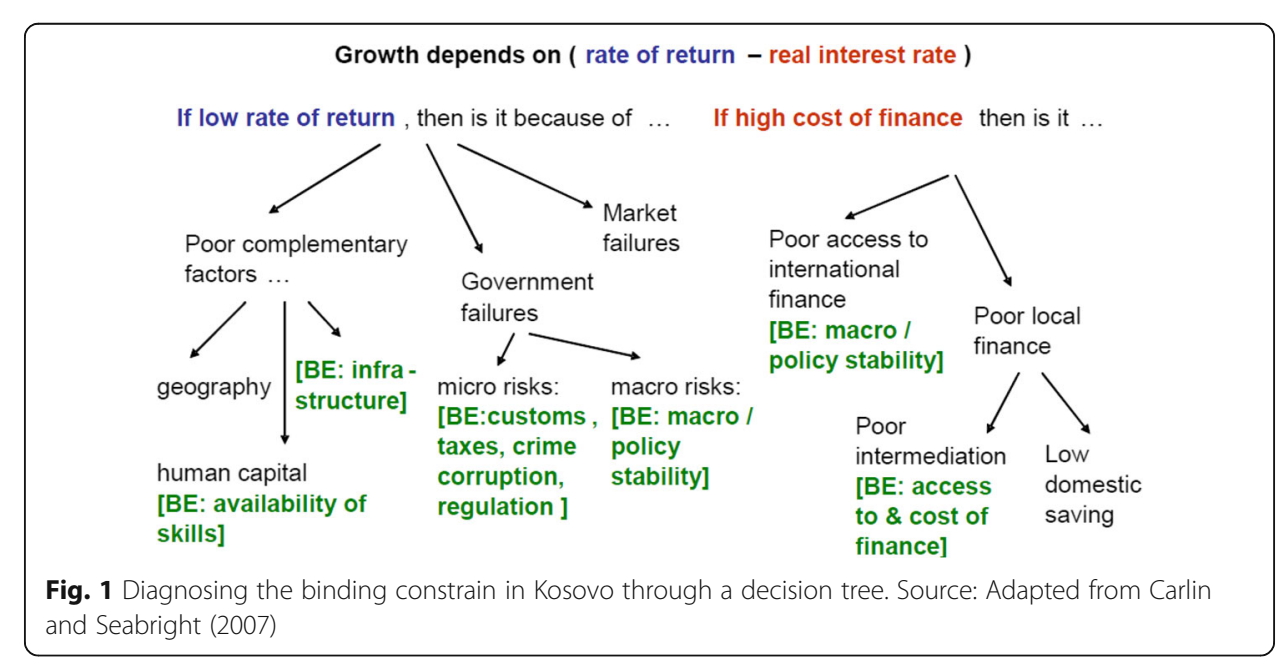


low growth is primarily a function of a low rate of private investment. If this be true, then a logical question to be raised is why? To investigate the reason why there is not enough private investment, the diagnosis process is carried out through three broad cause factors: high cost of finance, low appropriation or harvesting of profits, and low provision of complementary factors. In other words, entrepreneurs may not be willing to invest because the cost of capital to start or expand their business is high, because they perceive that their appropriation of profits will be low, and/or because the complementary factors such as physical infrastructure and human capital resources are poor. ${ }^{5}$

The process of analysis employed is carried out through three main steps. The first step provides background information which enables an understanding of the macroeconomic situation in the country. Although the background information may not add up to a diagnostic process, it still can establish important stylised facts that a potential diagnosis will need to account for (Hausmann et al. 2008). The second step is focused on investigating symptoms which enable the assessment of the tightness of different constraints to the growth of firms. However, in order to propose a theory or an explanation for the existence of binding constraints, the process of diagnosis is carried out through a logically consistent causal chain that as much as possible accounts for the facts observed (Hausmann et al. 2008). This leads to the third step which provides a causal story explained in the form of syndromes. Once syndromes are posited their soundness is checked by deriving other symptoms. This process is repeated until the diagnosis is settled on a well-supported identification of what the binding constraints to growth are and why they are present (Hausmann et al. 2008: 82).

Fundamentally, the 'growth diagnostics' is a top-down approach. However, supplied with manager survey data on the business environment, the process of analysis is complemented with a bottom-up approach. The bottom-up approach enables the creation of a candidate list of business environment constraints by including the manager/owners perspective. Figure 2 shows in a schematic way how these two perspectives are combined:

\section{Data}

This methodology tends to be pragmatic with respect to the kind of evidence used. The empirical evidence is obtained basically from two different sources. The first source of evidence is international surveys which create indices to assess the relative importance of countries in a wide set of dimensions. ${ }^{6}$ The main purpose is to measure the

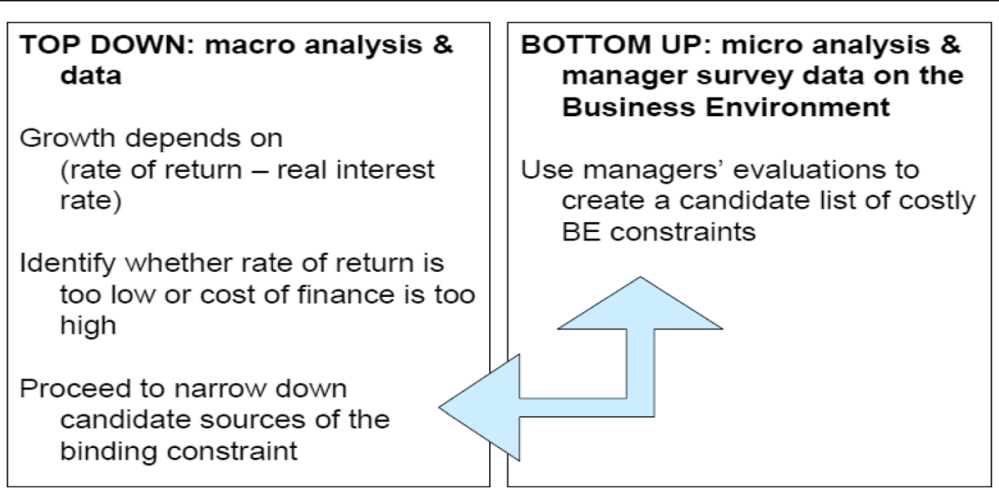

Fig. 2 Diagnosing binding constraint combining growth diagnostics with manager survey data. Source: Adapted from Carlin and Seabright (2007) 
performance of the country in a comparative manner by putting the country's performance in the context of other countries. Such diagnosis provides a very useful feedback about a country's performance in various political and economic indicators relative to what seems to be feasible (Hausmann et al. 2008).

The second source of data was obtained from a survey conducted by the Riinvest Institute in Kosovo. The survey was conducted in April 2013 and covered 600 firms. Firms were selected from a database issued by Tax Administration at the confidence interval of $99 \%$. The respondents were company owners/managers from all economic sectors, and all regions of Kosovo. The structure of the questionnaire, among others, included questions related to business environment barriers in which they operate. The questionnaire contained 24 obstacles, and managers of firms had to rank them from 1 (not at all obstacle) to 5 (very much obstacle).

\section{An overview macroeconomic profile of Kosovo}

The economic problems and challenges facing Kosovo are considerable. Historically, the economic growth of the country has been below the rate achieved in neighbouring countries. The level of per capita income is among the lowest in the region. Kosovo is listed by the World Bank in the group of lower-middle-income economies-with GNI per capita between \$ 1006 to 3975. The unemployment rate varies between 40 and $50 \%$. The economy is highly dependent on remittances and the international aid, which account for $22.5 \%$ of total GDP. ${ }^{7}$

Table 1 below shows that there is a trend of economic growth in the country, which primarily was driven by public spending, especially in infrastructure. ${ }^{8}$

The country's enterprise sector is dominated by small- and micro-sized firms, which make up $99.7 \%$ of total firms. The majority of these firms employ fewer than 50 people, contributing about $60 \%$ of the overall turnover in the economy. ${ }^{9}$ One of the biggest problems of the economy is the large informal economy. The problem is seen as being fuelled by weaknesses in tax and expenditure policies and in law enforcement, including the fight against corruption and organised crime (Riinvest Institute 2013). With regard to complementary factors (physical infrastructure), evidence shows that there has been a moderate progress. However, Kosovo still suffers from out-dated power and water systems, posing significant challenges to economic growth (World Bank 2012a, 2012b).

Table 1 Main economic indicators of Kosovo

\begin{tabular}{lllllll}
\hline & 2008 & 2009 & 2010 & 2011 & 2012 & $2013^{*}$ \\
\hline GDP (millions of Euros) & 3851 & 3912 & 4216 & 4637 & 4885 & 5169 \\
Growth of GDP (\%) & 6.9 & 2.9 & 3.9 & 5 & 2.7 & 3.2 \\
CPI, period average (\%) & 9.4 & -2.4 & 3.5 & 7.3 & 2.5 & 2.2 \\
Revenues, incl. interest income in \% of GDP & 24.5 & 29.3 & 27.6 & 28.1 & 27.8 & 27.6 \\
Exports (mill euro) & 218 & 177 & 305 & 322 & 289 & 307 \\
Imports (mill euro) & 1886 & 1851 & 2081 & 2412 & 2474 & 2566 \\
Trade balance (mill euro) & -1669 & -1673 & -1776 & -2090 & -2185 & -2259 \\
Foreign direct investment, net (mill euro) & 342 & 277 & 358 & 371 & 321 & 674 \\
Worker remittances (mill euro) & 535 & 506 & 512 & 548 & 557 & 568 \\
\hline
\end{tabular}

Source: IMF Kosovo Main Indicators, 2008-14 *2013 figures are only projections 
Human capital development remains one of the central issues for Kosovo. The evidence shows that quality of human resources in the country is significantly behind other countries in the region. The World Bank (2010)) notes that the level of formal education of employees is considerably lower than, for instance, other Central and Eastern European countries. The enrolment of the younger generation in vocational training is significantly low. Only $43 \%$ of students entered vocational schools in 2009/2010 compared to $71 \%$ in Croatia and $61 \%$ in FYR Macedonia (OECD 2013). The education system is not coordinated with labour market requirements, since students at vocational schools and universities are not acquiring skills and competences that are sufficiently aligned with labour market needs (OECD 2013). In terms of indicators related to institutional quality, the World Bank (2012a, 2012b) report shows that Kosovo is ranked considerably below comparator countries (Table 2).

Transparency International has ranked the country among the most corrupt countries-111th out of $177 .{ }^{10}$ In terms of doing business indicators for 2014, the World Bank has ranked Kosovo at 86th, which is a slight improvement compared with to 2013 (see Table 7 below).

With regard to the financial sector, there is no capital market operating in the country. The banking system is made up of nine banks, which account for more than $75 \%$ of total financial system assets (World Bank 2013a, 2013b, 2013c). The three largest locally incorporated banks are subsidiaries of European banks and together account for more than 70\% of bank assets (World Bank 2013a, 2013b, 2013c). According to the OECD (2012b), these banks encounter various difficulties, starting from asymmetric information, insufficient collateral, and a lack of a credit track record.

\section{Symptoms analysis using decision tree}

The symptoms analysis begins with the growth diagnostics decision tree, which enables the organisation of potential explanations. As previously stated, according to the

Table 2 The quality of institutions-Balkans countries

\begin{tabular}{|c|c|c|c|c|c|c|c|c|}
\hline & \multicolumn{8}{|c|}{ Percentile rank (0-100) } \\
\hline & Year & Alb & Cro & Kos & FYROM & Mntg & Srb & Rank \\
\hline \multirow[t]{2}{*}{ Voice and accountability } & 2007 & 51.44 & 61.54 & 36.54 & 55.29 & 55.77 & 56.73 & \\
\hline & 2012 & 50.24 & 63.51 & 42.18 & 49.76 & 56.4 & 55.92 & 6 \\
\hline \multirow[t]{2}{*}{ Political stability and absence of violence/terrorism } & 2007 & 37.98 & 67.31 & & 30.29 & 48.08 & 25.48 & \\
\hline & 2012 & 39.81 & 64.45 & 15.17 & 33.18 & 63.98 & 38.86 & 6 \\
\hline \multirow[t]{2}{*}{ Government effectiveness } & 2007 & 42.23 & 68.93 & 48.06 & 49.51 & 50.49 & 47.09 & \\
\hline & 2012 & 44.98 & 72.25 & 41.63 & 51.67 & 59.81 & 50.72 & 6 \\
\hline \multirow[t]{2}{*}{ Regulatory quality } & 2007 & 55.83 & 65.53 & 54.85 & 56.8 & 50.49 & 40.78 & \\
\hline & 2012 & 56.46 & 66.51 & 52.63 & 61.24 & 53.11 & 50.72 & 5 \\
\hline \multirow[t]{2}{*}{ Rule of law } & 2007 & 27.75 & 55.02 & 24.4 & 39.71 & 49.28 & 37.32 & \\
\hline & 2012 & 35.07 & 59.72 & 35.55 & 47.87 & 55.45 & 44.08 & 5 \\
\hline \multirow[t]{2}{*}{ Control of corruption } & 2007 & 29.61 & 59.22 & 23.79 & 44.66 & 48.54 & 45.63 & \\
\hline & 2012 & 26.79 & 57.42 & 30.14 & 59.33 & 55.02 & 48.33 & 5 \\
\hline
\end{tabular}

Source: Kaufmann, Kraay, and Mastruzzi. The Worldwide Governance Indicators: Methodology and Analytical Issues. These indicators are available at: www.govindicators.org

Note: The indicators are a research dataset summarising the views of the quality of governance provided by a large number of enterprise, citizen and expert survey respondents in industrial and developing countries. This data are gathered by a number of survey institutes, think tanks, non-governmental organisations, international organisations and private sectors firms. The WGI do not necessarily reflect the WB views 
growth diagnostics approach, the main obstacle to the growth of firms is the low rate of private investment. Therefore, the logical question to be raised is: what is constraining private investment and entrepreneurship? In order to conduct the symptoms analysis, the following assumptions are formulated:

- First, it is assumed that there are business projects available in the country, but private agents are not willing to invest because they cannot obtain required financial resources to invest in such projects at a reasonable cost (Hausmann et al. 2008).

- Second, it is assumed there are sufficient financial funds and at reasonable cost, but private agents are not willing to invest either because the overall public goods are low (poor infrastructure, poor human capital), or because the proportion of the returns that could be privately appropriated is low.

In the quest for symptoms of the low level of private investment and entrepreneurship, the analysis will start with the right-hand side of the decision tree.

The right-hand side of the decision tree-financial story. If it is assumed that there are plenty of investment opportunities that could be privately profitable but finance is constraining (high interest rates), the logical question is why? Two stories can be constructed: (i) interest rates are high because of inadequate access to savings, and (ii) interest rates are high because of the size of the financial system, namely the issue is related to the capacity to mobilise those savings.

Arguing that inadequate saving is the cause of constraint, several symptoms need to be presented. First and foremost banks should be willing to remunerate savings with a high interest rate. If banks remunerate savers at a high real rate, it means that firms in the country find it harder to access external finance. The evidence suggests that interest rates on deposits in Kosovo are not significantly higher than comparator countries in the region. However, as Table 3 shows, business interest rates are significantly higher than in comparator countries.

Kosovo has the widest spread of interest rates in the region. The wide spread of interest rates between deposits and loans is seen to be as a result of market bank inefficiencies, such as high transaction costs and asymmetric information (Stiglitz and Weiss 1981). The main transaction costs included here are those related to selecting, analysing the quality, and monitoring of the borrowers. The higher these inefficiencies are, the higher the interest spread will be. In the last 2 years, the average operating cost ratio for the three most profitable banks in the country is around 55\% (Table 4).

The second symptom related to the story of savings is that the access of the country to foreign borrowing is restricted. ${ }^{11}$ Is there a symptom which indicates that Kosovo

Table $\mathbf{3}$ Interest rates on deposits and on business loans

\begin{tabular}{llllllll}
\hline & Year & Alb & Cro & Kos & FYROM & Mne & Srb \\
\hline Household & 2010 & n/a & n/a & 5.1 & 5.4 & n/a & 3.8 \\
Deposits & 2012 & n/a & n/a & 4.8 & 4.1 & n/a & 5.3 \\
Business & 2013 & n/a & 10.37 & 6.12 & 7.2 & 8.9 & 7.3 \\
Loans & 2012 & n/a & 5.97 & 11.1 & 6.8 & 8.5 & 6.3 \\
\hline
\end{tabular}

Source: World Bank (2012a, 2012b) 
Table 4 Interest rate spreads (lending minus deposit rate), 2009-2012

\begin{tabular}{lllll}
\hline & 2009 & 2010 & 2011 & 2012 \\
\hline Alb & 5.9 & 6.4 & 6.6 & 5.5 \\
Cro & 8.4 & 8.6 & 8 & 7.6 \\
Kos & 10.1 & 10.9 & 10.2 & 9.1 \\
FYROM & 3 & 2.4 & 3 & 3.4 \\
Mne & 5.5 & 5.8 & 6.6 & 6.3 \\
Srb & 6.7 & 6 & 7.4 & 7.6 \\
\hline
\end{tabular}

Source: World Bank (2012a, 2012b)

has little or very restricted access to foreign finance? One way to investigate this is analyse the country's sovereign risk or credit risk. Kosovo is still not listed on Standard \& Poor, one of the most prestigious organisations assessing the countries' sovereign risk. The fact that potential investors and credit organisations have no trustworthy way to measure the investment and credit risk represents a major drawback. Foreign creditors therefore apply a high-risk premium, which obviously increases the cost of funding from foreign creditors.

The volume of gross domestic savings could indicate that the cost of finance is constraining. Table 5 below shows that despite the fact that the negative rate has fallen from comparatively high levels earlier in the decade, Kosovo continues to have very unfavourable rates of domestic savings in comparison to comparator countries (except for Montenegro).

The second story constructed in the search for symptoms related to the cost of finance is the size of the financial system in the country. In terms of the size of the banking system, relative to the population, the number of banks operating in the market is the second lowest in the region. Return on assets (ROA) and return on equity (ROE) data in Table 6 show that banks in Kosovo enjoy greater profits than comparator countries. The small size of the banking system gives an indication that bank competition in the economy is reduced, banks enjoy greater profits, and as a result interest rates in Kosovo are higher than in comparator countries.

Micro analysis and manager survey findings on the financial intermediation story. With regard to the cost of finance, the analysis of the data from manager surveys conducted in Kosovo suggests that firms do not view it as the most binding constraint. Among 24 different areas, access to finance is viewed as a moderately problematic obstacle, contradicting the World Bank survey which has listed the access to finance as the second binding constraint. The cost of finance is ranked as 10th with the score 3.56.

Table 5 Gross domestic savings, 2004-2012 (per cent of GDP)

\begin{tabular}{llllllllll}
\hline Gross domestic & 2004 & 2005 & 2006 & 2007 & 2008 & 2009 & 2010 & 2011 & 2012 \\
\hline Alb & 2 & 0 & 1 & 4 & 6 & 4 & 4 & 3 & 7 \\
Cro & 21 & 21 & 23 & 22 & 23 & 21 & 21 & 21 & 20 \\
Kos & & & -11 & -10 & -10 & -6 & -5 & -5 & -5 \\
FYROM & 2 & 4 & 4 & 6 & 2 & 4 & 7 & 8 & 6 \\
Mne & 1 & 0 & -4 & -8 & -14 & -6 & -6 & -6 & -6 \\
Srb & 2 & 3 & 3 & 5 & 3 & 5 & 7 & 2011 & \\
\hline
\end{tabular}

Source: World Bank (2012a, 2012b) 
Table 6 Distribution of banks per population

\begin{tabular}{llllll}
\hline Country & No. of banks & Banks vs population & ROA & ROE & Req. Res. Ratio \\
\hline Albania & 16 & 176.3 & 0.3 & 3.8 & n/a \\
Croatia & 34 & 129 & 0.9 & 4.8 & n/a \\
Kosovo & 9 & 196.2 & 0.7 & 7.2 & $10 \%$ \\
Macedonia & 17 & 131.6 & $\mathrm{n} / \mathrm{a}$ & $\mathrm{n} / \mathrm{a}$ & $\mathrm{n} / \mathrm{a}$ \\
Montenegro & 11 & 56.4 & 0.18 & $\mathrm{n} / \mathrm{a}$ & $\mathrm{n} / \mathrm{a}$ \\
Serbia & 32 & 224.6 & 0.4 & 2.1 & $\mathrm{n} / \mathrm{a}$ \\
\hline
\end{tabular}

Source: Annual reports of central banks (2014) of respective countries

For managers, other obstacles such as unfair competition, corruption, crime, theft, and unrest, followed by unfair practices and uncertain economic policies, are more constraining for growth (Fig. 3).

To sum up, the cost of finance can be potentially considered as a binding constraint to the growth for Kosovo's firms. This is indicated specifically by findings on the volume and the prices of domestic savings, findings on the wide spread between deposit and lending loans, poor access to international finance, and the size of the banking system.

The left-hand side of the decision tree-low return to economic activity. The process of analysis now proceeds under the assumption that finance is not a problem, but that private agents are not willing to invest because they expect that the proportion of the returns that could be privately appropriated is low. This is either because a private agent fears that, due to government failures, the expected returns could be dissipated by others through planned or surprise hold-up problems, or because of market failures.

With regard to government failures, emphasis is given to microeconomic hold-up problems such as corruption, crime, rule of law (court efficiency), or macroeconomic hold-up problems such as uncertain economic policies, lack of political stability, and monetary and fiscal stability. Prestigious international institutions publish findings on all of the abovementioned variables. For instance, the World Bank publishes six indicators of institutional quality that map into the appropriation problems. These indicators include the rule of law, voice and accountability, political stability, government effectiveness, regulatory quality, and control of corruption.

As Fig. 4 below shows, in terms of institutional quality factors, compared to other comparator countries, Kosovo is ranked significantly unfavourably. ${ }^{12}$ If indicators such

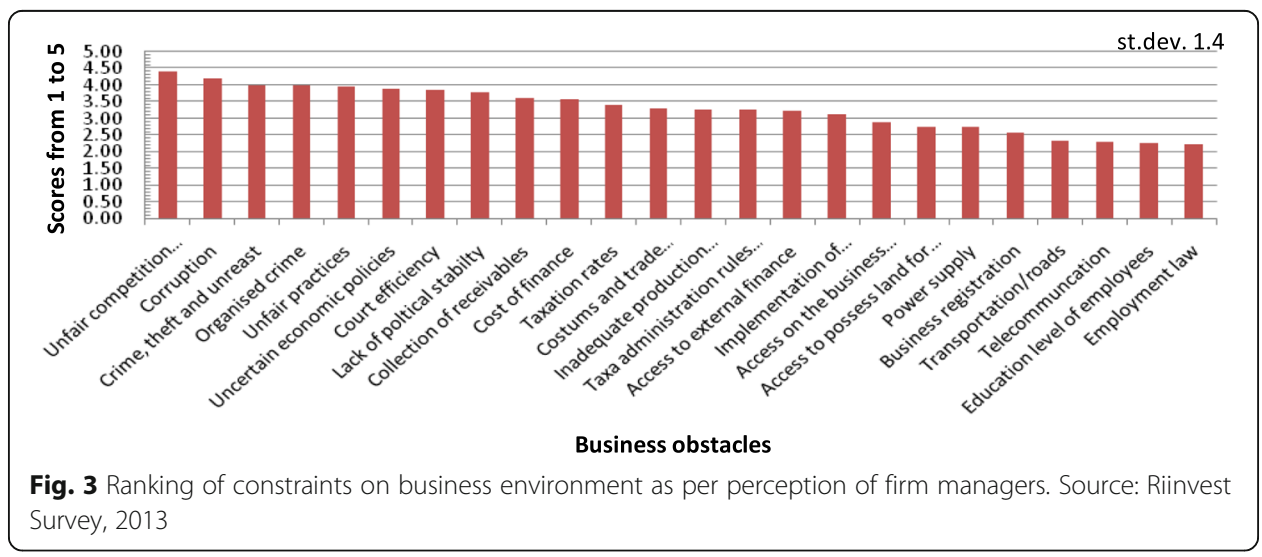


as rule of law, or control of corruption are compared, for instance to Croatia, scores associated to Kosovo are considerably worse. This could be taken as a symptom that the country is significantly more sensitive than other comparator countries to poor government performance in most indicators. A closer look indicates that the country has been able to formulate sound policies and regulations that permit and promote private sector development (World Bank 2012a, 2012b) compliance with laws and regulation is the main issue.

With regard to taxation, when compared to other comparator countries, the rates are relatively low. Corporate income tax is similar to other countries while VAT is better than in most countries. Moreover, according to the World Bank/Doing Business Indicators 2014, tax rates are one of the least problematic business environment factors in the country. This report has ranked Kosovo as 46th out of 177 countries (Table 7).

Interestingly, findings from firm-level survey highlight quite a different picture. Taxation rates and tax administration rules as obstacles have been scored relatively high by managers. The mean for tax rates is 3.41 , meaning that $41.2 \%$ of respondents view tax rates as an obstacle, while the mean related to tax administration rules is 3.28 , and $40 \%$ of respondents view the administration rules as an obstacle (see Fig. 3 above). Though these findings may be a reflection of the subjective nature of responses, there is an association between the above findings and findings related to the corruption in the tax administration. So, when managers were asked about the level of corruption in the tax administration, $55 \%$ of them responded positively.

The problems with appropriation are not only linked with government failures, but also with market failures such as information externalities (self-discovery) and coordination externalities. Both could potentially be factors that constrain the growth of firms. ${ }^{13}$ The structure of exports is unfavourable and remains unchanged throughout the last decade. This is a sign that there is a lack of self-discovery among firms. However, having in mind the small manufacturing base that exists in the country and that Kosovo's economy is very slowly emerging out of a post-war situation, problems with informational externalities are unavoidable. For an economy which is not yet an integral part of the world's economy, arguing that problems with informational externalities are binding probably is not grounded (Sen and Kirkpatrick 2011).

With respect to coordination failures, the SME Policy Index published by the OECD (2012a, 2012b) shows how small and medium-size firms in Kosovo face difficulties in representing their views to the government. ${ }^{14}$ Despite some reported improvements,

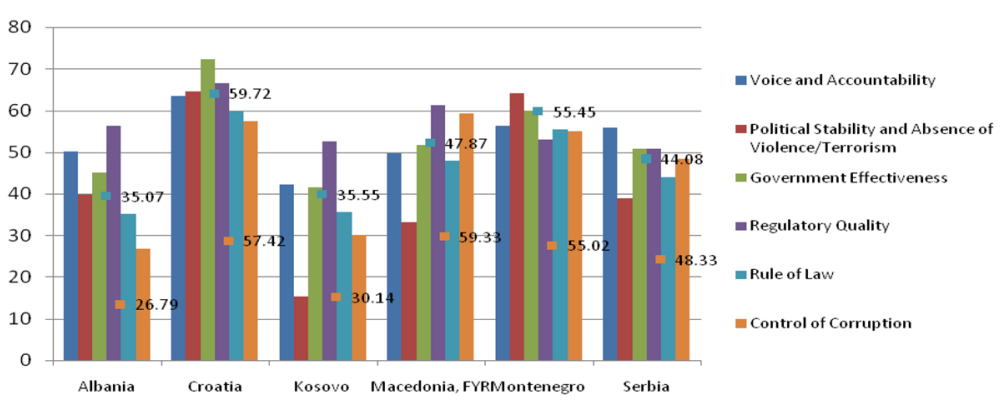

Fig. 4 Six indicators of institutional quality—Kosovo and comparator countries. Source: The World Bank, the Worldwide Governance Indicators 
Table 7 Tax rates in Kosovo and comparator countries

\begin{tabular}{llll}
\hline Country & Corporate income tax & Value added tax (VAT) & Doing Bus. Rank (2014) \\
\hline Albania & $10 \%$ & $20 \%$ & 146 \\
Croatia & $20 \%$ & $25 \%$ & 34 \\
Kosovo & $10 \%$ & $16 \%$ & 46 \\
Macedonia & $10 \%$ & $18 \%$ & 26 \\
Montenegro & $9 \%$ & $17 \%$ & 86 \\
Serbia & $10 \%$ & $20 \%$ & 161 \\
\hline
\end{tabular}

Source: World Bank, Doing Business Indicators (2014)

the SME support services provided by the government and formal consultations between the government and the private sector remain deficient compared to other comparator countries. In general terms, the lack of comprehensive, easily accessible, and regularly updated information on issues relevant to SMEs is seen to be a significant constraint for small businesses operating in the country (see the Fig. 5 below).

Micro analysis and manager survey findings on appropriation problems. The analysis of the data from manager surveys suggests that Kosovan entrepreneurs perceive appropriation problems as the largest barrier. Of the 10 most highly ranked barriers, 8 are related to government performance. For instance, $70 \%$ of interviewed managers perceive corruption as a very high obstacle, while unfair competition and informality is rated as the most severe obstacle ( $76 \%$ assess as a very high obstacle). While sources of unfair competition may be different, the survey findings suggest that unfair competition in Kosovo is primarily driven by two components, tax evasion and labour informality. The results of the survey indicate that $84 \%$ of respondents consider unfair competition as the main business constraint. According to the survey findings, 34.4\% of total sales are not taxed, meaning that firms in Kosovo declare only $65.6 \%$ of their sales. With regard to the other sources of unfair competition, as seen by the interviewed managers, their perception is that firms in the country report only $63 \%$ of their employees to the tax authorities. One explanation of how firms manage to avoid taxes and declaration of employees is through the perception of firms about the corrupt practices in the central and local government, the judicial system and tax administration. On the question of whether they view the above institutions as being corrupt, $72 \%$ of them believe that central government is corrupt, $68 \%$ believe that local authorities are corrupt, judicial

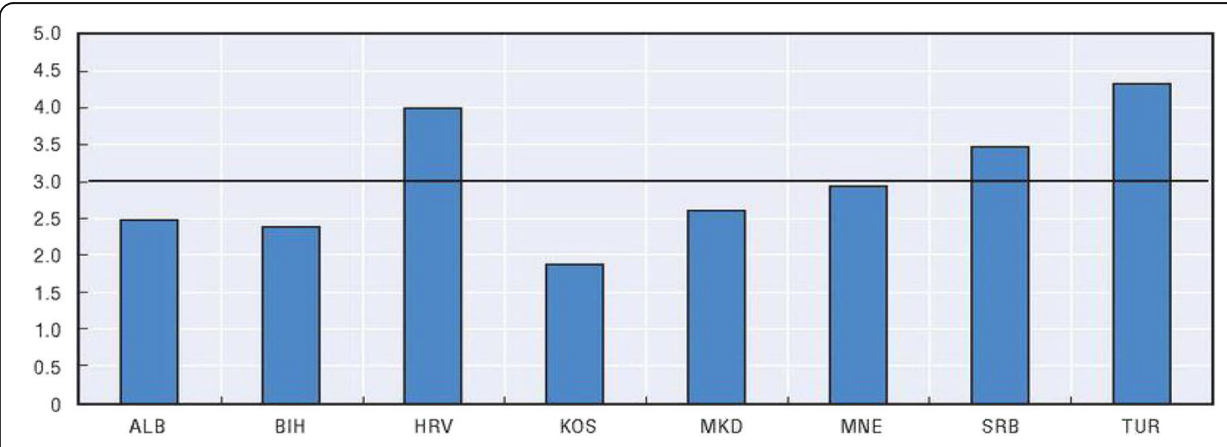

Fig. 5 Overall scores for Dimension 5a: Support services for SMEs and start-ups. Note: The line indicates the regional average of the policy dimension. Source: SBA assessment 2012 
system 64 , while tax administration was scored by $53 \%$. Other macro level variables also have very high scores (the means 3.90 respectively 3.78 ) (Fig. 6). ${ }^{15}$

The evidence shows clearly that unfair competition and corruption are assessed by managers as the strongest obstacles. ${ }^{16}$

With regard to the relationship between the business community and central as well as the local government, the evidence obtained from firm-level survey shows that $55.5 \%$ of respondents have no trust in local government, while $50.1 \%$ of them have no trust in national government. This is another symptom that illustrates that coordination activities and trustful relationship between these two bodies leave a lot to be desired.

In conclusion, in terms of government failures, there is clear evidence indicating that the business environment is heavily constrained by ineffective and inefficient government institutions. As a result, corruption is viewed as uncontrolled and crime is seen as a lucrative area. Thus, due to the high level of tax evasion and the size of the informal economy, unfair competition/practices are seen as a major constraint, and the rule of law is highly defective. Micro-manager survey and findings from other sources are consistent and fit the perception that the low level of investment by the private sector is a function of government failures.

The left-hand side of the decision tree-complementary factors. According to the decision tree, one of the reasons why firms are not growing could be the poor geography of the country. In the case of Kosovo, probably it is not easy to argue that the geographical position of the country could have any significant impact on the growth of firms. Being located in the south east European region close to the European Union market suggests that on balance, Kosovo's geographical location cannot be considered as a binding constraint.

In terms of infrastructure, the country has made some improvements in the last 5 years. Major government spending has been concentrated on the improvement of road infrastructure. However, other infrastructure elements remain in poor conditions. Kosovo still has an out-dated power system. It is inadequate and unreliable, posing significant challenges to economic growth; frequent outages hamper investment and disrupt manufacturing, education, and health services (World Bank 2012a, 2012b). A similar situation exists with the water supply.

An important variable related to complementary factors is the quality of human capital. Though human capital is not ranked by managers as one of the top constraints,

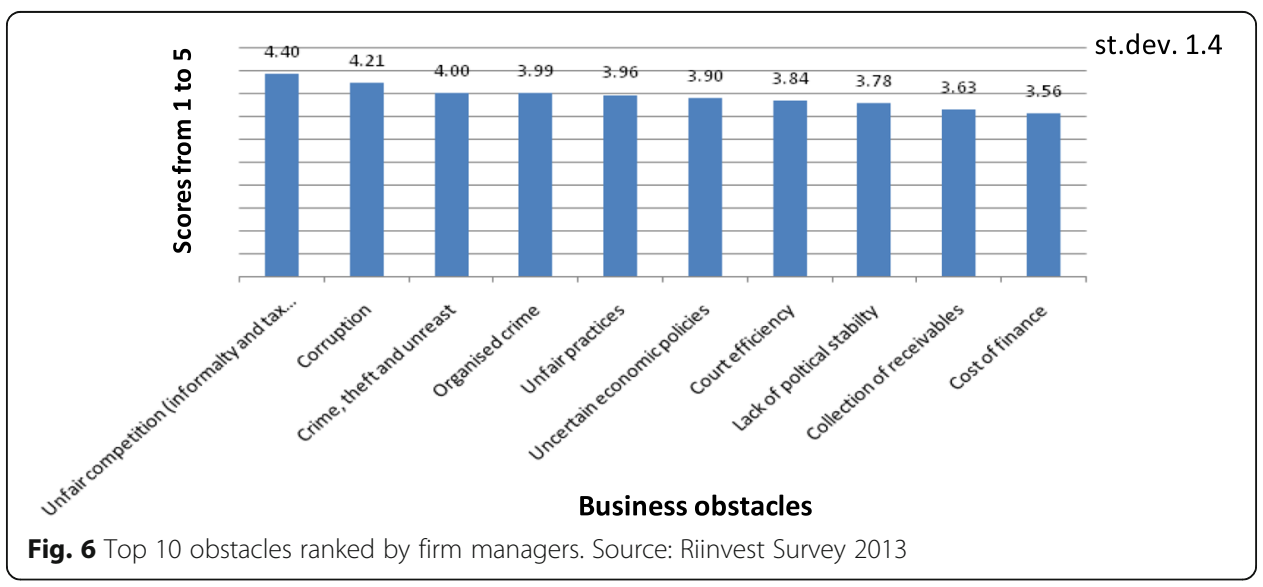


there are other symptoms generated from other sources which argue that human capital might be one of binding constraints to the growth of firms. Hausmann et al. (2008) argue that one way to look at whether human capital is binding is to use the Mincerian model on returns to human capital. According to this model, if returns on education are high, then it can be inferred that human capital is a binding constraint. However, in countries such as Kosovo, characterised with a very high unemployment rate of unskilled workers and slow growth in less skill-intensive tradable activities including manufacturing, it is hard to argue that high returns to education is a signal that human capital is a binding constraint to growth (Rodrik, 2010). There have been studies showing that return to education in Kosovo is low. However, this low return may be due to the high level of unemployment in which workers tend to trade lower wages in return for more secure employment (Hoti, 2011).

There are other signals which may shed light on current human capital conditions in the country. Under the assumption that profits are appropriable, government provides decent services to firms, there are no market failures, and access to finance is not a problem. Could it be inferred that the current education system in the country generates human capital which is in line with market demand? ${ }^{17}$

In one of the OECD reports generated in 2013, it is reported that one of the major problems with human capital and specifically with the education system in Kosovo is its structure. From the total number of students in the higher education, only $5.6 \%$ of them study natural and mathematical sciences and 3.4\% electrical and computer engineering. Other unfavourable signals are the relationship between universities and firms, in which the internship system is either applied partially or not at all. There is a general view among firms that students that graduate in Kosovo's universities, both private and public ones, lack applied skills (OECD 2013). ${ }^{18}$

The OECD also provides data on how well countries manage to apply principles adopted by the Small Business Act (SBA) for Europe 2008. ${ }^{19}$ One of the main principles of this act is related to entrepreneurship learning and training. More specifically, the report assesses the ability of various countries to build coherent entrepreneurship skills through national education systems. According to the report published in 2012, Kosovo has not managed to establish a specific policy framework for promoting entrepreneurship learning in higher education. The report also argues that Kosovo has not established the link between universities and firms. The comparative analysis shows that in terms of entrepreneurship learning and inclusion of entrepreneurship into the education system, the country lags behind many countries in the Western Balkans.

Findings in the manager survey (2013) provide a slightly different picture. In the list of 24 business environment factors included in the questionnaire, recruitment of educated and skilled employees as a constraint was ranked quite low, with the mean scored at 2.22 (Fig. 6). This could, however, be due to the fact that managers address current requests rather than latent ones.

Micro analysis and manager survey findings on complementary factors. The analysis of the data from the manager survey indicates that complementary factors are no longer seen as major constraints. Compared to governance performance indicators, the means for complementary factors are almost twice lower. Table 8 below shows that from three major complementary factors (power supply, telecommunication, and infrastructure/roads), power supply is seen to be most constraining. 
Based on the findings from external sources and micro-manager surveys, it can be concluded that there are a few symptoms that indicate that firms suffer from lack of adequate human capital. Findings from both OECD reports illustrate that the education system in the country is not oriented towards promotion of entrepreneurship learning. There is no well-structured relationship between private sector firms and universities. The government has not undertaken any formal initiative to implement the principles set out in the Small Business Act 2008.

The process of analysis carried out above is aimed at identifying symptoms that constrain the growth of firms. These symptoms provide signals which may serve to make a structured list of the kinds of tests that help discriminate between different explanations. The ultimate objective is to match symptoms with the relative tightness of constraints. In Table 9 each column shows a constraint, while each row shows the number of symptoms identified during the second step of the analysis.

As is shown in Table 9, there are two assumptions taken into account. The first one stands for the situation when the cost of finance is high, and possible explanations as to why interest rates are so high are listed. In situations when aggregate savings are a problem, it would be expected to see a high deposit rate, because money is scarce. Also, foreign borrowing could be limited. As a consequence of that, the interest rate will be high.

On the right hand of Table 9, the assumption involves a situation in which lending is available and cheap but does not trigger much investment. The columns provided below provide symptoms related to government and market failures, as well as complementary factors such as infrastructure and human capital.

\section{From symptoms to syndromes}

In the previous step, the aim was to assess the tightness of different symptoms/signals to the growth of firms. Now the aim is to organise the findings and propose an explanation for the existence of the syndromes/constraints and why they are present.

Syndrome 1: poor provision of public goods. As previously explained, the purpose of growth diagnostics theory is not only to identify the symptoms but more importantly to explain from whence they come. Therefore, where a market is perfect, the shortage of a constraint would generate incentives to increase the supply (Hausmann et al. 2008). So why does the constraint not self-correct? In other words, the logical question is what departures from the normal business environment are included? For firms to grow the first requisite factor is publicly provided goods, such as the existence of law and order. Data from both sources leads to the inference that poor public goods provided in

Table 8 Ranking of complementary factors by means and percentage of respondents

\begin{tabular}{lllll}
\hline Constraint & N & Mean & Std. deviation & $\%$ \\
\hline 1 Unfair competition (informality and tax evasion) & 499 & 4.4 & 1.597 & 72.3 \\
2 Corruption & 499 & 4.21 & 1.898 & 65.3 \\
3 Crime, theft, and unrest & 499 & 4 & 2.027 & 57.5 \\
19 Power supply & 499 & 2.74 & 1.859 & 22.2 \\
21 Transportation/roads & 499 & 2.33 & 2.01 & 12.6 \\
22 Telecommunication & 499 & 2.28 & 2.111 & 9.4 \\
\hline
\end{tabular}

Source: Riinvest survey 2013 


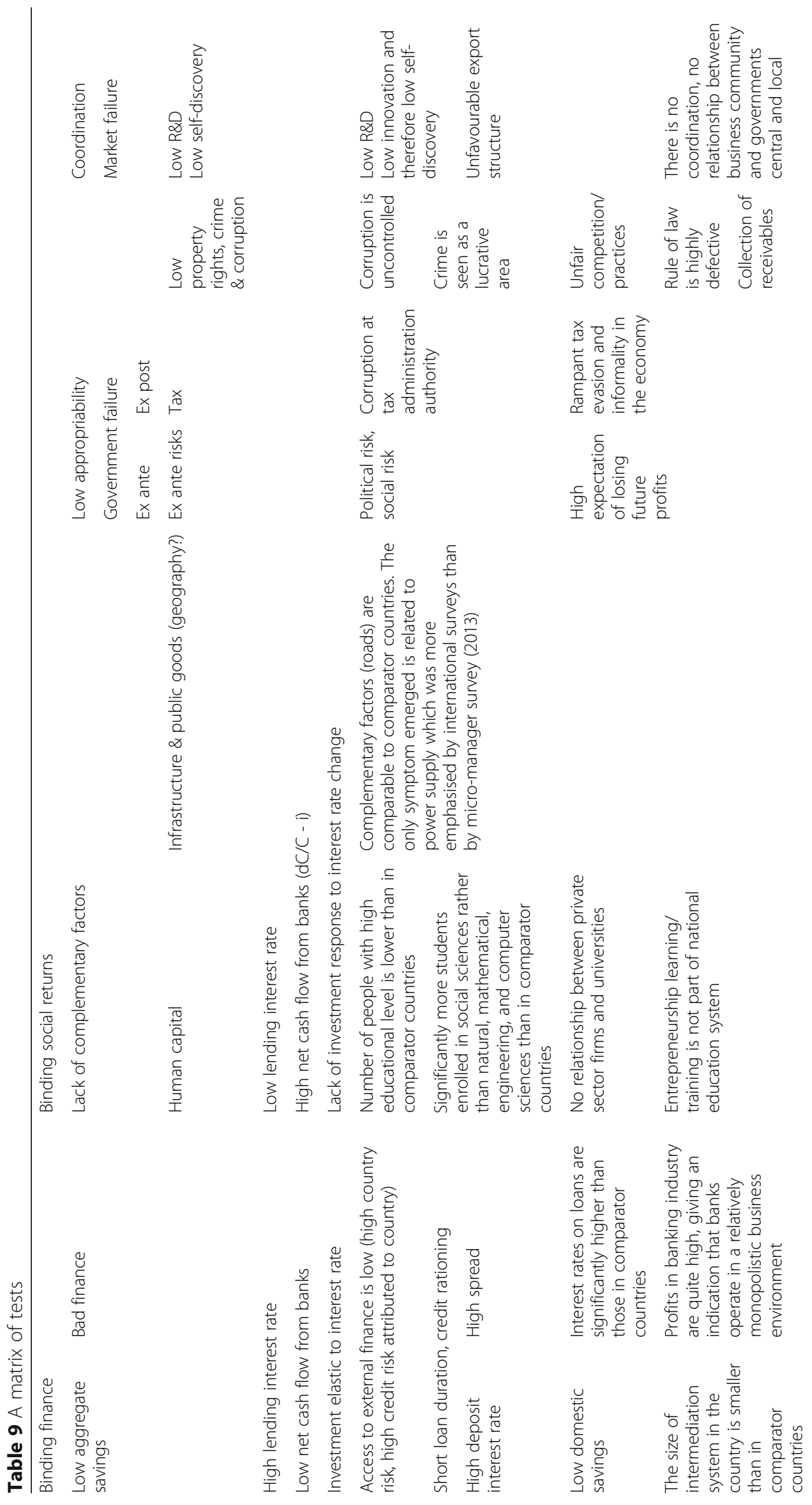


Sahiti and Smith Journal of Innovation and Entrepreneurship (2017) 6:16

Page 17 of 24

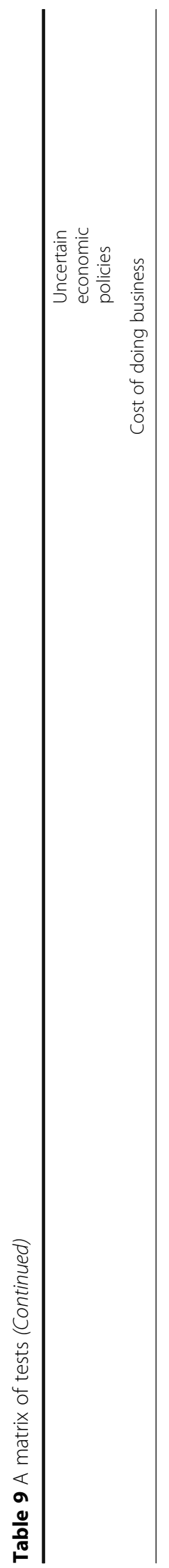


the country emerge as an empirical regularity-a syndrome. Therefore, it can be inferred that based on the evidence found, poor public goods (for example, law and order) provided in a country can be the decisive cause of the low rate of private investment in the country. This inference is supported by evidence and facts on the ground presented by various international surveys, and reinforced by micro analysis and the manager survey conducted in Kosovo by Riinvest Institute in 2013 (see Table 8 above) (Fig. 7).

In the World Bank reports on Kosovo, the governance indicators are scored quite low as against comparator countries, such as Croatia, Serbia, Montenegro, or Macedonia. For instance Kosovo is ranked relatively highly in terms of the control of corruption, an indicator which converges with data provided by other sources such as the Transparency International Corruption Perceptions Index, and by the MicroManager survey (Riinvest 2013). ${ }^{20}$ The survey results indicate that $76 \%$ of respondents perceive that in Kosovo unfair competition is the most binding constraint, followed by corruption (63\%) and crime (57.5\%).

Alleviation of appropriation constraints (informality, rule of law, corruption, and unfair competition) would potentially have positive effects on other constraints. First, by better control of tax evasion and informality, good governance could restore fairer competition in the marketplace. Second, by improving the rule of law, reduction of corruption would improve the country's rating and by doing that the country's risk, and thus most importantly, the country's credit risk rating, would improve. Third, under the assumption that the country's risk and the credit risk are improved, the prospects for better access to foreign finance would increase. Fourth, as a consequence of all the above improvements, the high cost of finance would decrease.

In summary, based on the evidence, it can be inferred that low appropriation-government failures-represent the first and the biggest syndrome of the business environment in Kosovo. More specifically lack of law and order is reflected through high levels

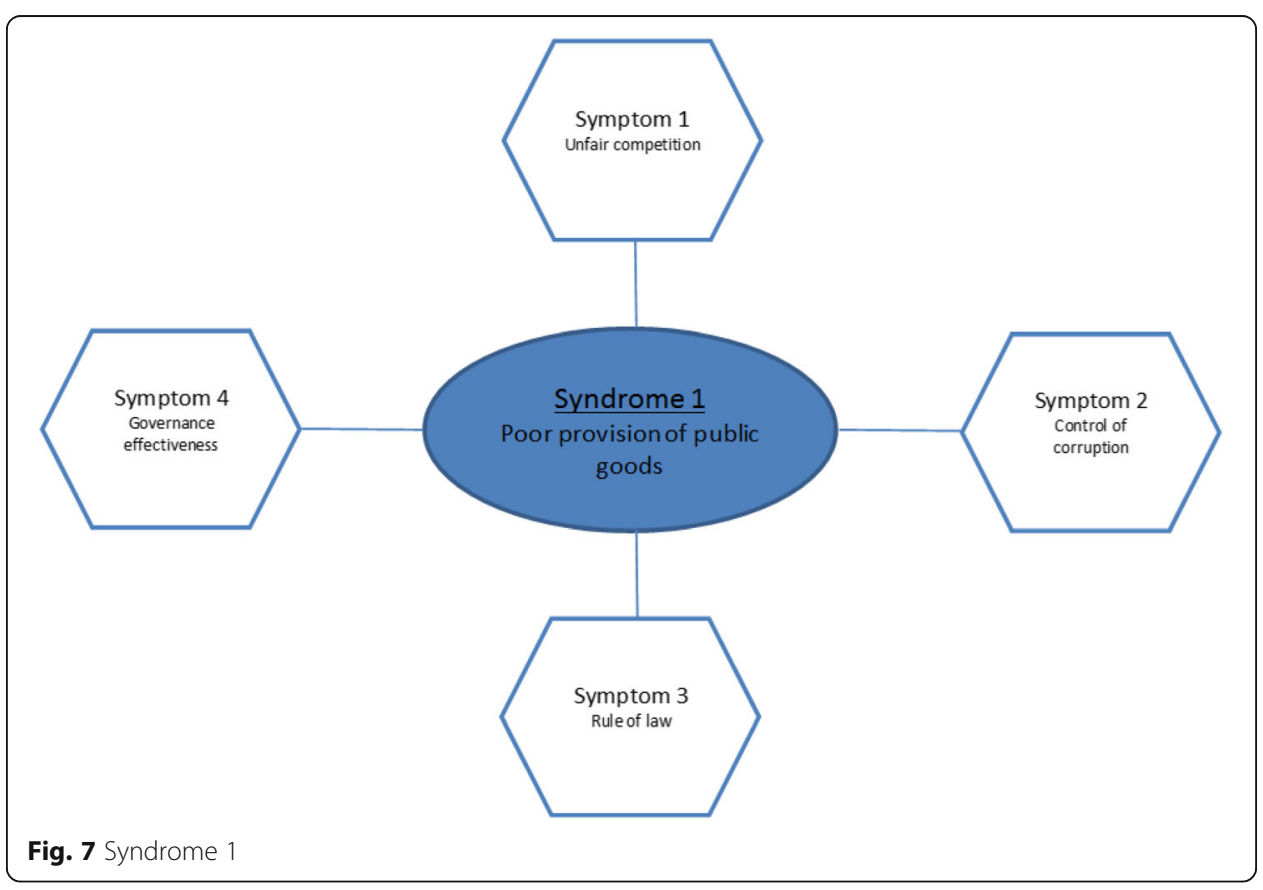


of unfair competition, informality, uncontrolled corruption, court inefficiency, and governance effectiveness.

Syndrome 2: cost of finance. Many empirical studies indicate that finance is one of the major constraints to the growth of firms. There have been studies relating to Kosovo which even ranked the access to external finance as the most binding constraint (Sen and Kirkpatrick 2011). The evidence and analysis conducted in this study shows that finance is a binding constraint, but not the most binding one. There are symptoms which correlate to each other and as such lead to the inference that finance is one of the constraints which firms face currently in the Kosovo's business environment (see Table 7). The findings show that domestic savings in the country is the lowest in south-eastern Europe. Due to the country's risk and the unfavourable credit rating, access to foreign finance is restricted and the cost is relatively high, the interest rate on deposits is high and therefore the interest spread is the highest in the region. There are symptoms that the banking sector is monopolised (high profits and the small size of the banking sector).

This evidence converges with the managers perception collected in the 2013 survey dataset. Though the cost of finance and access to finance are not ranked higher than factors related to governance factors, managers still perceive that the cost of finance as being a significant constraint (Fig. 8).

Syndrome 3: human capital. From complementary factors such as geography and infrastructure (roads, power supply, and water), and human capital, the evidence shows that human capital has enough symptoms to be treated as the third binding constraint. Several symptoms point out that the education system is in a poor state.

First, evidence presented by international organisations (specifically OECD 2013 and UNESCO, 2012) shows that in many aspects Kosovo lags behind other comparator countries. For instance, the percentage of people with a high education in the country is far less than in other comparator countries (for example Croatia and Montenegro). The structure of the education system in the country is very skewed towards social sciences rather than for

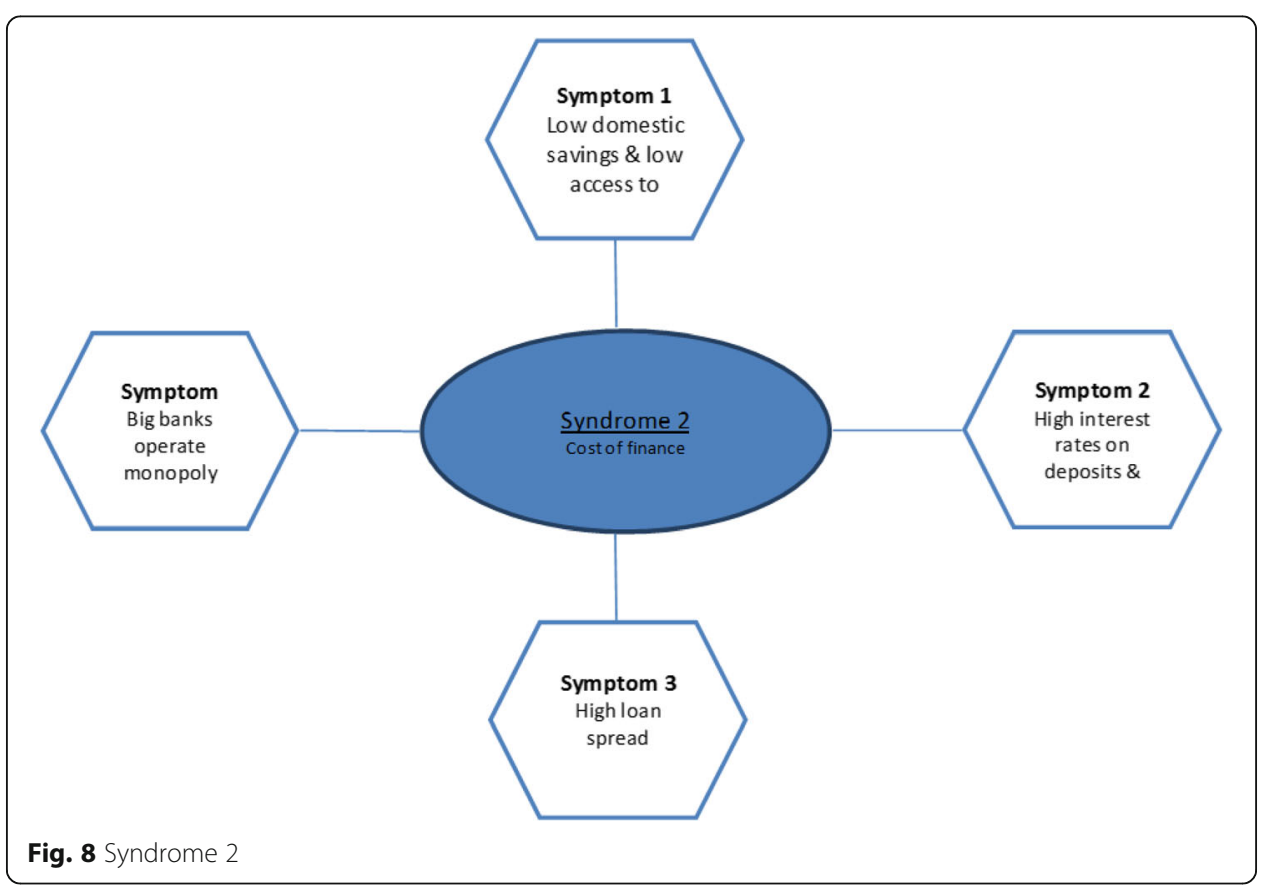


instance natural, mathematical, engineering, and computer sciences. The current education system has not started to implement the OECD's Small Business Act which requires that entrepreneurship learning and training be part of the national education system. This project has started to be implemented in other countries such as Macedonia, Croatia, and Serbia. The higher education system in Kosovo is not linked with research and innovation activities as it is the case with some education systems in comparator countries (for example Croatia).

Another symptom found is related to the relationship between universities and business entities. The evidence shows that students get very broad and theoretical knowledge from their studies, since they are not required to conduct the practical part of their study in the form of an internship (OECD 2013).

With regard to infrastructure, the evidence shows there are signs of improvement, and this factor is becoming more comparable with other countries in the region (Fig. 9).

\section{Discussion}

Though the GD approach provides a well-structured methodology to think about why there is a low level of private investments and entrepreneurship, yet there are some limitations related to this framework. The first limitation is related to the identification of symptoms/signals. An underlying idea of this framework is to find symptoms/signals that guide the diagnostics process. The process requires searching for both price and non-price signals, specifically the shadow resource prices. The process of measuring shadow prices is not easy, and sometimes the use of indirect evidence for judging the scarcity of a resource is inevitable. Second, the GD approach assumes the main growth problem is the low level of private investment and entrepreneurship. However, growth may result from public investments as well (OECD 2009; Sutherland et al. 2009). The third limitation related to the GD methodology lies in its static nature. This methodology is centred on constraints that are binding today, but not necessarily in the future. However, the problem of many economies, particularly in developing countries such as

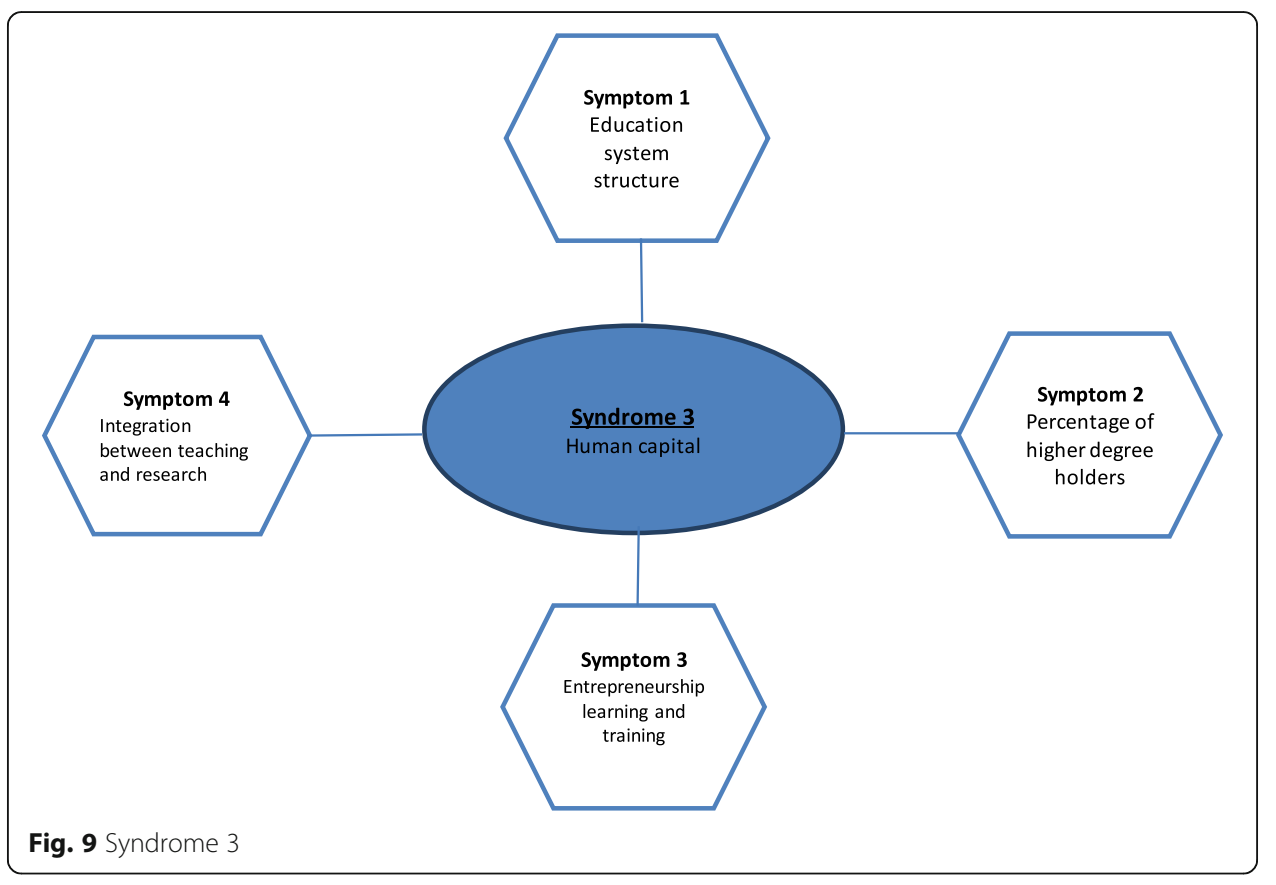


Kosovo, is not how to start growth but how to sustain the growth process. The key element is to look at growth factors primarily from the dynamic perspective, namely what makes growth of firms sustainable.

\section{Conclusions}

The purpose of this paper was to investigate the binding constraints to the growth of firms in an economic setting characterised by low income, with reference to Kosovo's economy. The focus of the investigation was on those aspects of the business environment that are not under the control of business entities, but that affect the expense, ease, and reliability of doing business in the country. The process of investigation was conducted by applying the growth diagnostics approach and methodology. This model provides methodological principles to identify what are the most binding externalities to the growth of firms in a particular economy by taking into account the institutional context and socio-economic realities of the country in question. The empirical evidence used to test the hypotheses is taken from various sources: rankings and surveys conducted by various international organisations and from the subjective evaluation of constraints by managers of 600 firms operating in Kosovo. The conclusions provided below have been derived by combining the top-down growth diagnostics approach with bottom-up survey data from managers.

Findings point out that the most binding constraint is related to poor provision of public goods by the government. This is indicated by micro-risk factors such as unfair competitive practices, rule of law, and high levels of corruption. These outcomes indicate that improvement in provision of public goods would produce bigger change in the objective function. The second binding constraint is related to the cost of finance. This constraint is partly related to the macro- and microeconomic risk factors. Specific symptoms have been discerned in relation to the high cost of finance. The evidence indicates that factors that encourage the high cost of finance are related to the low level of domestic savings, monopolistic behaviour of banks, and poor access on international finance. The third binding constraint is related to complementary factors, particularly to poor availability of human capital.

If the central argument of a growth diagnostics approach and methodology is that private investment and entrepreneurial activity is essential for any country to experience growth, then, based on the evidence presented in this paper, it could be inferred that the current investment climate in Kosovo provides little incentive for the growth of firms. Growth is a function of private investments, which increases only when agents (entrepreneurs) expect a high rate of return on asset accumulation, and also when there is an availability of funds to finance their business projects. The findings show that private investors perceive the business environment in Kosovo as being unfavourable, characterised by high microeconomic risks, where the cost of capital is high, and in which complementary factors in the form of human capital are extensively scarce.

Having said that it does not mean that other external constraints are trivial or not important. This paper has explored the sequence of binding constraints that firms in Kosovo currently face. This is a reason why the study should be treated as a work in progress, because changes in the business environment occur constantly, new data and evidence may become available, and therefore updating the list of binding constraints becomes necessary. In sum, in the light of future possible changes in the country, this work should be viewed as working hypotheses that have to be challenged, and extended by other research studies. 


\section{Endnotes}

${ }^{1}$ Information failure is defined as the failure of firms to 'discover' which products they can produce at low enough cost to be profitable and competitive. Coordination failure is defined as the failure of the market to respond to potential investors' demands for a diverse set of services.

${ }^{2}$ Some of the studies include Hausmann (2005) on Tanzania; Hausmann and Klinger (2007a, 2007b) on Paraguay and Peru; Hausmann and Rodrik (2005) on el Salvador; Sen and Kirkpatrick (2011) on Kosovo.

${ }^{3}$ By symptom is understood a feature that is associated to a specific variable, for instance low level of domestic savings is regarded as a symptom of high interest rates.

${ }^{4}$ A syndrome represents a group of symptoms that consistently occur together or a condition characterised by a set of associated symptoms.

${ }^{5}$ By appropriation is meant the environmental factors that govern a firm's ability to capture profits.

${ }^{6}$ International surveys were obtained from the following organisations: Freedom House, the World Economic Forum, Transparency International, the World Bank, OECD. Indicators on the voice and accountability, political stability, rule of law, regulatory quality, control of corruption, and government effectiveness, indicators on the efficiency and costs of business regulations in over 170 developing countries based on standardised pre-selected transactions, a mix of subjective indicators (for example raking of constraints) and objective indicators (for example how many power outages last year) (Hausmann et al. 2008]).

${ }^{7}$ USAID, 'USAID/Kosovo Strategic Plan 2010-2014, May 20, 2010.

${ }^{8}$ IMF Country Report, December 2012.

${ }^{9}$ Kosovo Agency for Statistics (http://esk.rks-gov.net/eng/)

${ }^{10}$ Croatia - 57/177, Albania - 116/177, Montenegro - 67/177, Macedonia FYR - 67/ 177, Serbia - 72/177.

${ }^{11}$ As Hausmann et al. (2008) argue, saving can in theory move internationally, if capital mobility was perfect it could be expected that there would be the same interest rate in all countries.

${ }^{12}$ Voice and Accountability (VA) - capturing perceptions of the extent to which a country's citizens are able to participate in selecting their government, as well as freedom of expression, freedom of association, and a free media (World Bank 2012a, 2012b).

${ }^{13}$ Information failures arise when firms fail to 'discover' which products they can produce at low enough cost to be profitable and competitive.

${ }^{14}$ Coordination failures arise when the market fails to respond to potential investors' demands for a diverse set of services.

${ }^{15}$ Corruption in this study is defined as the misuse or the abuse of public office for private gain and it is reflected in various forms and a wide array of illicit behaviour, including bribery, extortion, fraud, nepotism, graft, speed money, pilferage, theft, misappropriation, falsification of records, kickbacks, influence peddling, and campaign contributions.

${ }^{16} \mathrm{By}$ unfair competition is meant when firms compete in the market on unequal terms, that is situations when favourable or unfavourable conditions are applied to some firms but not to others; or that the actions of some firms actively harm the position of others with respect to their ability to compete on equal and fair terms.

${ }^{17}$ Creation of an education system which would be more focused towards technical and natural sciences and not rely on current demand but on latent demand. 
${ }^{18}$ There are 18 private universities and colleges, and 5 public universities operating in the country (OECD 2013)

${ }^{19}$ Adopted in June 2008, the Small Business Act for Europe reflects the Commission's political will to recognise the central role of SMEs in the EU economy and for the first time puts into place a comprehensive SME policy framework for the EU and its Member States http://ec.europa.eu/growth/smes/business-friendly-environment/smallbusiness-act_en

${ }^{20}$ https://www.transparency.org/country/KOS

Acknowledgements

The authors acknowledge the kind help of John Slater in the editing of this paper.

\section{Funding}

The authors of this paper declare that there were no external sources of funding for the research reported in this paper.

The design of the study, data collection, analysis, and interpretation of data were conducted by using personal funds.

\section{Authors' contributions}

FS made a substantial contribution into the conception and design of this paper, acquisition of data, analysis and interpretation of data. The co-author of this paper, HLS, has had a crucial role in drafting the paper, as well as revising it critically for important intellectual content. Both authors read and approved the final manuscript.

\section{Competing interests}

The authors declare that they have no competing interests.

\section{Publisher's Note}

Springer Nature remains neutral with regard to jurisdictional claims in published maps and institutional affiliations.

Author details

${ }^{1}$ Rochester Institute of Technology (R.I.T), Prishtina, Kosovo. ${ }^{2}$ Birkbeck, University of London, London, UK.

Received: 19 April 2017 Accepted: 27 July 2017

Published online: 07 August 2017

\section{References}

Acedo, F. J., Barroso, C., Casanueva, C., \& Galán, J. L. (2006). Co-authorship in management and organizational studies: An empirical and network analysis. Journal of Management Studies, 43(5), 957-983.

Aidis, R., \& Mickiewicz, T. (2006). Entrepreneurs, expectations and business expansion: Lessons from Lithuania. Europe-Asia Studies, 58, 855-880.

Aidt, T. (2011). Corruption and sustainable development. In S. Rose-Ackerman \& T. Søreide (Eds.), International handbook on the economics of corruption, volume 2. Cheltenham: Edward Elgar.

Aterido, R., \& Hallward-Dreimeier, M. (2010). —the impact of the investment climate on employment growth. World Bank Policy Research Working Paper 5218.

Aterido, R., \& Hallward-Dreimeier, M. (2011). Big constraints to small Firms' growth: Business environment and employment growth across firms. Economic Development and Cultural Change, 59(3), 609-647 Available online at http://www.jstor.org/stable/10.1086/658349.

Aterido, R., Hallward-Driemeier, M., \& Pages, C. (2009). Big constraints to small Firms' growth: Business environment and employment growth across firms. In Policy research working paper 5032. Washington DC: World Bank. Available on line at http://go.worldbank.org/SE95ERXW0.

Barney, J. B. (1991). Firm resources and sustained competitive advantage. Journal of Management, 17, 99-120.

Barney, J. B. (2001). Is the resource-based view a useful perspective for strategic management research. Academy of Management Review, 26(1), 41-56.

Barney, J. B., Ketchen, D. J., \& Wright, M. (2011). The future of resource-based theory: Revitalization or decline. Journal of Management, 37(5), 1299-1315.

Barr, H., Koppel, I., Reeves, S., Hammick, M., \& Freeth, D. (2005). Effective inter-professional education: Argument, assumption \& evidence. Oxford: Blackwell Publishing.

Bevan, A., \& Estrin, S. (2004). The determinants of foreign direct investment into European transition economies. Journal of Comparative Economics, 32(4), 775-787.

Carlin, W., \& Seabright, P. (2007). Bring me sunshine: Which parts of the business climate should public policy try to fix? Available at http://www.ucl.ac.uk/ uctpa36/ABCDE\%20Carlin\%20Seabright\%202007.pdf.

Carlin, W., Schaffer, M., Seabright, P. (2006). Where are the real bottlenecks? A Lagrangian approach to identifying constraints on growth from subjective survey data, CEPR discussion paper 5719.

Davidsson, P., \& Honig, B. (2003). The role of social and human capital among nascent entrepreneurs. Journal of Business Venturing, 18(3), 301-331.

Dinh, H. T., Mavridis, D. A., Nguyen, H. B. (2010). The binding constraint on firms' growth in developing countries. Policy Research working paper; no. WPS 5485. Washington, DC: World Bank. http://documents.worldbank.org/curated/en/ 966571468137388733/Thebinding-constraint-on-firms-growth-in-developing-countries. 
Dollar, D., Hallward-Driemeier, M., \& Mengistae, T. (2005). "Investment climate and firm performance in developing economies", Economic Development and Cultural Change, 54, 1-31.

Estrin, S., Meyer, K., \& Bytchkova, M. (2006). Entrepreneurship in transition economies. In M. Casson (Ed.), The Oxford handbook of entrepreneurship (pp. 693-723). Oxford: Oxford University Press.

Estrin, S., Hanousek, J., Kočenda, E., \& Svejnar, J. (2009). Effects of privatization and ownership in transition economies. Journal of Economic Literature, 47(3), 699-728.

Filatotchev, I., \& Mickiewicz, T. (2006). Private benefits of control and debt financing. In T. Mickiewicz (Ed.), Corporate governance and finance in Poland and Russia (pp. 159-176). Houndmills: Palgrave Macmillan.

Gelb, A., Ramachandran, V., Shah, M. K., \& Turner, G. (2007). What matters to African firms? The relevance of perceptions data. In Policy research working paper 4446. Washington, DC: World Bank.

Grant, R. M. (1991). "The resource-based theory of competitive advantage: Implications for strategy formulation", California Management Review, 30(3) pp. 114-135.

Grant, R. (1996). Toward a knowledge-based theory of the firm. Strategic Management Journal, 17(Winter Special Issue), 109-122.

Hashi, I., \& Toci, V. (2010). Financing constraints, credit, rationing, and financing obstacles: Evidence from firm level data in South Eastern Europe. Business and Economic Review, 12(1), $29-59$.

Hausmann, R. (2005). Tanzania comments. Growth path workshop (pp. 1-2). Washington, D.C.: The World Bank.

Hausmann, R., \& Klinger, B. (2007a). Growth diagnostic: Belize. Cambridge: Center for International Development.

Hausmann, R., \& Klinger, B. (2007b). Growth diagnostic: Peru. Cambridge: Center for International Development.

Hausmann, R., \& Rodrik, D. (2005). Self-discovery in a development strategy for El Salvador. Brainstorming on growth analysis methodology (GAM). Washington, D.C: Inter-American Development Bank.

Hausmann, R., Rodrik, D., \& Velasco, A. (2005). Growth diagnostics. Harvard University mimeo.

Hausmann R. Bailey K., and Rodrigo W., (2008). Doing growth diagnostics in practice: A "Mindbook." Harvard University Center for international development working paper 177.

Hoti, A. (2011). "Returns for education in Kosovo: Estimates of wage and employment premia", South East European Journal of Economics and Business, 6(1), 71-84.

Johnson, S., Kaufmann, D., McMillan, J., \& Woodruff, C. (2000). Why do firms hide? Bribes and unofficial activity after communism. Journal of Public Economics, 76(3), 495-520.

Kogut, B. \& Zander, U. (1992). 'Knowledge of the firm, combinative capabilities, and the replication of technology', Organization Science, 3, 383-397.

Lee, N. (2014). What holds back high-growth firms? Evidence from UK SMEs. Small Business Economics, 43(1), 183-195.

McMillan, J., \& Woodruff, C. (2002). The central role of entrepreneurs in transition economies. Journal of Economic Perspectives, 16(3), 153-170.

Mickiewicz, T. (2005). Economic transition in Central Europe and the commonwealth of independent states. Houndmills: Palgrave Macmillan.

OECD. (2009). Strategies for aligning stimulus measures with long-term growth. Paris: OECD.

OECD. (2012a). Review of the National Innovation System: Former Yugoslav Republic of Macedonia. Paris: OECD.

OECD. (2012b). SME policy index: Western Balkans and Turkey 2012: Progress in the implementation of the small business act for Europe. Paris: OECD Publishing doi: http://dx.doi.org/10.1787/9789264178861-en.

OECD, (2013). Assessment of the Kosovo innovation system. RCI project paper, OECE development, march 2013.

Pissarides, F. (1999). Is the lack of funds the main obstacle to growth? EBRD's experience with small and medium-sized businesses in central and Eastern Europe. Journal of Business Venturing, 14, 519-539.

Riinvest Institute. (2013). A business perspective of informality in Kosovo http://www.fes-prishtina.org/wb/media/ Publications/2013/BUSINESS_INFORMALITY_ENG_FINAL.pdf.

Rodrik, D. (2010). Diagnostics before prescription. Journal of Economic Perspectives, 24(3), 33-44.

Rodrik, D., Subramanian, A., \& Trebbi, F. (2004). Institutions rule: The primacy of institutions over geography and integration in economic development. Journal of Economic Growth, 9(2), 131-165.

Rosen, H. S. (2005). Public finance (7th ed.). New York: McGraw-Hill Irwin.

Sen, K., \& Kirkpatrick, C. (2011). A diagnostics approach to economic growth and employment policy in low income economies: The case of Kosovo. Journal of International Development, 23(1), 132-154.

Stiglitz, J., \& Weiss, A. (1981). Credit rationing in markets with imperfect information. American Economic Review, 71(3), 393-409.

Sutherland, D., Sonia, A., Balázs, É., Tomasz, K., (2009). Infrastructure investment: Links to growth and the role of public policies. Economics department working paper no. 686 ECO/WKP(2009)27.

Svejnar, J. (2002). Transition economies: Performance and challenges. Journal of Economic Perspectives, 16(1), 3-28.

Tell, J. (2015). Journal of Innovation and Entrepreneurship. 4: 9. doi:10.1186/s13731-015-0023-7.

UNESCO. (2012). Data Centre, UNESCO Institute for Statistics website. http://stats.uis.unesco.org/unesco/TableViewer/ document.aspx?Reportld=136\&IF_Language=eng\&BR_Topic=0BR_Topic=0. Accessed 25 Nov 2012.

Wehinger, G. (2014). SMEs and the credit crunch OECD. Journal: Financial Market Trends, 2013(2), 115-148.

World Bank. (2012a). Country partnership strategy (2012).

World Bank. (2012b). World development report 2013: Jobs. Washington, DC: World Bank.

World Bank (2013a). BEEPS (2013). Washington D.C: Kosovo, Business Environment and Enterprise Performance Survey (BEEPS M), World Bank http://www.enterprisesunveys.org/ /media/GIAWB/EnterpriseSurveys/Documents/Profiles/English/kosovo-2013.pdf.

World Bank. (2013b). Doing business report 2013. World Bank. https:/www.ihk-krefeld.de/de/media/pdf/international/ doing-business/kosovo-doing-business-in-kosovo-2013.pdf.

World Bank. (2013c). Kosovo Overview.

World Bank. (2010). BEEPS At-A-Glance 2008 Kosovo, Business Environment and Enterprise Performance Survey (BEEPS IV). Washington DC: World Bank. 